\title{
PENGARUH BENTONIT PER ORAL TERHADAP PENURUNAN KADAR GLUKOSA DARAH TIKUS MODEL DIABETES MELITUS YANG DIINDUKSI ALOKSAN MONOHIDRAT
}

\author{
Galuh Alviana $^{1}$, Hendro Sudjono Yuwono ${ }^{2}$, Nova Sylviana ${ }^{3}$ \\ ${ }^{\mathbf{1}}$ Fakultas Kedokteran, Universitas Padjadjaran, Bandung, Indonesia, \\ ${ }^{2}$ Departemen Ilmu Bedah, Rumah Sakit Umum Pusat Dr. Hasan Sadikin Bandung, Indonesia, \\ ${ }^{3}$ Divisi Fisiologi, Fakultas Kedokteran, Universitas Padjadjaran, Bandung, Indonesia.
}

\begin{abstract}
In Indonesia, it is estimated that there would be increasing in number of diabetes mellitus patients become 12 million cases in 2030. The expensive cost of conventional medications motivates people to find alternative medication. Bentonite is a natural clay which is a good absorbent and frequently called as healing clay for its potency in body detoxification. This study is an experimental research to prove bentonite which is a good absorbent and adsorbent in decreasing blood glucose concentration in diabetes mellitus. Subject of this research is 20 female Wistar rats which weigh 150-250 g. These subjects were divided into two groups: control group and bentonite group. Diabetes is induced by alloxan monohydrate $150 \mathrm{mg} / \mathrm{kg}$ intraperitoneally, causing $\beta$ cell necrosis in pancreas. Result of independent t-test showed that bentonite could significantly lower blood glucose levels with average value of $131.30 \mathrm{mg} / \mathrm{dL}(p=0.010)$. This concludes that bentonite can reduce blood glucose level in diabetic-induced rats.
\end{abstract}

Keywords: bentonite, diabetes mellitus, hyperglycemia, Wistar rats

Korespondensi: Redaksi JIFO, Laboratorium Sentral, Universitas Padjadjaran, Jalan Raya Jatinangor KM. 21, Sumedang, Jawa Barat, Indonesia. E-mail: amrosdianto@ gmail.com 


\section{PENDAHULUAN}

Penyakit diabetes melitus adalah suatu kelompok penyakit metabolik dengan tanda utama hiperglikemia. ${ }^{1}$ Selain itu, ditandai juga dengan komplikasi vaskular, mata, saraf, dan ginjal. ${ }^{2,3}$ Terjadinya penyakit diabetes melitus ini diakibatkan terjadinya defisiensi dari hormon insulin di dalam tubuh baik karena kelainan sekresi, kelainan fungsi, ataupun keduanya. ${ }^{4}$ Terdapat tiga gejala khas yang selalu dikeluhkan pasien diabetes melitus, yaitu polidipsi, poliuri, dan polifagi. $^{3}$ Gejala ini seringkali kurang diperhatikan pasien sehingga diagnosis dari diabetes melitus menjadi terlambat. ${ }^{5}$

Pada tahun 2000, di Indonesia terdapat 8,4 juta pasien diabetes dan diprediksi angka ini akan semakin meningkat sampai pada tahun 2030 akan mencapai angka 21,3 juta jiwa., Peningkatan ini tidak hanya terjadi di daerah perkotaan, tetapi juga terjadi di daerah pedesaan. ${ }^{4}$

Diabetes melitus belum dapat disembuhkan sehingga penyandang akan menderita seumur hidup. Walau demikian, penyakit diabetes melitus dapat dikontrol dengan obat-obatan., ${ }^{4,5}$ Kencangnya isu back to nature dan turunnya daya beli masyarakat terhadao obat-obatan modern

\section{METODE}

Subjek penelitian yang digunakan adalah tikus betina galur Wistar (Rattus norvegicus). Sebelum penelitian, tikustikus ini diadaptasikan selama 7 hari sebelum diberikan bahan uji di laboratorium Farmakologi Fakultas Kedokteran Universitas Padjadjaran. ${ }^{12}$

Pada penelitian ini terdapat 2 kelompok perlakuan dan ditentukan akan menggunakan 20 tikus, sehingga terdapat 10 tikus untuk masing-masing kelompok. Kelompok 1 diberikan aloksan monohidrat iintraperitoneal $150 \mathrm{mg} / \mathrm{kgBB}$ dan diberikan intervensi aquades $5 \mathrm{~mL} / \mathrm{kgBB}$ sebagai kontrol. Kelompok 2 diberikan aloksan monohidrat intraperitoneal $150 \mathrm{mg} / \mathrm{kgBB}$ dan diberikan larutan bentonit $0,25 \mathrm{gram}$ per oral. Kriteria inklusi untuk dijadikan hewan coba adalah: (1) berat tikus 150-250 gram, (2) tikus dalam akhir-akhir ini mengakibatkan adanya kecenderungan terhadap pengobatan dengan bahan alami. Akan tetapi, penggunaan bahan alami ini didasarkan pada pengalaman dan pengetahuan masyarakat secara turun-temurun. ${ }^{7}$

Obat tradisional adalah bahan atau ramuan bahan, baik tumbuhan, hewan, mineral, sediaan sarian atau campuran dari bahan-bahan tersebut, yang diterapkan secara turun-temurun sesuai norma yang berlaku dalam masyarakat. ${ }^{8,9}$ Bentonit merupakan sejenis tanah liat aklami keluarga dari mektit yang mempunyai kemampuan menyerap air dan zat-zat yang terkandung di dalamnya dan disebut sebagai salah satu healing clay. ${ }^{10}$ Kemampuan penyembuh dari bentonite ini disebabkan karena golongan tanah smektit di permukaan luarnya memiliki muatan negatif yang cenderung akan menarik molekul-molekul polar sehingga akan menarik larutan dan substrat yang memiliki kandungan ion positif. ${ }^{11}$

Penelitian ini dilakukan untuk mengetahui efek bentonite terhadap penurunan kadar glukosa darah yang tinggi pada tikus yang diinduksi menjadi diabetes.

keadaan sehat (3) tikus berusia 8-12 minggu. Kriteria eksklusi penelitian ini adalah: (1) tikus yang sakit, dan (2) tikus yang sudah pernah dilakukan uji coba penelitian sebelumnya.

Penelitian dilakukan secara eksperimental dengan fokus untuk melihat dan mengetahui adanya efek penurunan konsentrasi glukosa pada model tikus diabetes melitus dengan menggunakan metode pre and post test control group design.

Data hasil penelitian berupa kadar glukosa darah tikus dianalisis menggunakan program Statistical Pacjage for the Social Sciences (SPSS) ofr Windows versi 15 . Untuk mengetahui perbandingan efek bentonite, akan digunakan uji t-tidak berpasangan jika data berdistribusi normal, atau menggunakan 
uji non-parametrik Mann-Whitney $U$ apabila distribusi data tidak normal.

Penelitian dilaksanakan pada bulan

Oktober-November 2012 di Laboratorium
Farmakologi Fakultas Kedokteran Universitas Padjadjaran Bandung.

\section{HASIL}

Dalam penelitian ini digunakan sebanyak 20 ekor tikus Wistar betina sehat yang terbagi menjadi 2 kelompok masingmasing berjumlah 10 ekor, yaitu kelompok kontrol yang diberikan aquades $5 \mathrm{~mL}$, dan

kelompok bentonit. Setelah diinduksi aloksan monohidrat, perlakuan dilakukan selama empat hari. Hasil pengukuran kadar glukosa darah ditunjukkan pada tabel 1 .

Tabel 1. Pengukuran kadar glukosa tikus Wistar pada kelompok aquades dan bentonit

\begin{tabular}{|c|c|c|c|c|c|c|c|c|c|}
\hline \multirow{2}{*}{ Kelompok } & \multicolumn{3}{|c|}{ G0 } & \multicolumn{3}{|c|}{ G1 } & \multicolumn{3}{|c|}{ G2 } \\
\hline & $\overline{\mathrm{x}}$ & \pm & SB & $\overline{\mathrm{x}}$ & \pm & SB & $\overline{\mathrm{x}}$ & \pm & SB \\
\hline Aquades & 100,60 & \pm & 3,406 & 291,70 & \pm & 62,029 & 291,20 & \pm & 155,108 \\
\hline Bentonit & 103,60 & \pm & 8,303 & 434,40 & \pm & 113,416 & 132,60 & \pm & 70,091 \\
\hline \multirow[t]{5}{*}{ Keterangan } & \multicolumn{9}{|c|}{ G0 Pemeriksaan awal (hari ke-0) } \\
\hline & \multirow{2}{*}{\multicolumn{9}{|c|}{$\begin{array}{l}\text { G1 Pemeriksaan setelah diinduksi aloksan monohidrat (hari ke-3) } \\
\text { G2 Pemeriksaan glukosa setelah perlakuan (hari ke-7) }\end{array}$}} \\
\hline & & & & & & & & & \\
\hline & \multicolumn{9}{|c|}{$\overline{\mathrm{x}}$ Rerata } \\
\hline & \multicolumn{9}{|c|}{ SB Simpangan baku } \\
\hline
\end{tabular}

Tabel 2. Analisis komparasi rerata peningkatan kadar glukosa darah awal dan setelah induksi aloksan monohidrat

\begin{tabular}{lccccc}
\hline Pemeriksaan & $\mathbf{N}$ & Rerata \pm SB & $\begin{array}{c}\text { Perbedaan } \\
\text { rerata } \pm \text { SB }\end{array}$ & $\begin{array}{c}\text { IK } \\
\mathbf{9 5 \%}\end{array}$ & Nilai p \\
\hline $\begin{array}{l}\text { Kadar glukosa } \\
\text { darah awal }\end{array}$ & 10 & $102,1 \pm 6,365$ & & 201,718 & \\
$\begin{array}{l}\text { Kadar glukosa } \\
\text { darah setelah } \\
\text { induksi }\end{array}$ & 10 & $356,75 \pm 112,524$ & $254,65 \pm 113,09$ & $\begin{array}{c}- \\
307,582\end{array}$ & $<0,001$ \\
\hline
\end{tabular}

Tabel 3. Hasil analisis kadar glukosa darah dari masing-masing kelompok perlakuan setelah pemberian perlakuan

\begin{tabular}{lccc}
\hline Kelompok & $\mathbf{N}$ & Rerata \pm SB & Nilai p \\
\hline Aquades & 10 & $291,2 \pm 155,108$ & \multirow{2}{*}{0,01} \\
Bentonit & 10 & $131,3 \pm 46,166$ & \\
\hline
\end{tabular}

Berdasarkan data pada tabel 1, kadar glukosa darah tikus sebelum diinduksi aloksan monohidrat berkisar antara $100,5-103,6 \mathrm{mg} / \mathrm{dL}$. Setelah diinduksi aloksan monohidrat menjadi diabetes jadar glukosa darah tikus mengalami peningkatan berkisar antara 291,7 - 434,4 mg/dL. Kemudian, setelah diberi perlakuan selama empat hari,kadar glukosa darah tikus diabetes di kelompok aquades cenderyng tetap sedangkan di kelompok bentonit menurun.

Analisis efek induksi aloksan monohidrat diuji berdasarkan rerata kadar glukosa darah antara kelompok sebelum dengan sesudah diberikan perlakuan. Oleh karena distribusi data normal, maka digunakan uji t-berpasangan. Hasil uji disajikan pada tabel 2 .

Tabel 2 menunjukkan bahwa terjadi peningkatan rerata kadar glukosa darah secara signifikan sehingga dapat disimpulkan bahwa efek induksi aloksan monohidrat dalam meningkatkan kadar glukosa darah berhasil dengan peningkatan rerata sebesar $254,65 \mathrm{mg} / \mathrm{dL}$.

Selanjutnya dilakukan analisis efek perlakuan yang diuji berdasarkan kadar glukosa darah antar kelompok setelah masing-masing diberikan aquades 
dan bentonit. Hasil analisis menggunakan uji t-tidak berpasangan dan disajikan dalam tabel 3.

Berdasarkan hasil uji t-tidak berpasangan, diperoleh hasil perbedaan yang signifikan $(p<0,05)$ antar kelompok perlakuan. Hal ini menjelaskan bahwa

\section{DISKUSI}

Dari hasil data yang didapatkan dari penelitian serta uji statistik menggunakan uji t-tidak berpasangan, didapatkan bahwa bentonit memiliki efek menurunkan kadar glukosa darah tikus galur Wistar diabetes akibat induksi aloksan monohidrat.

Induksi menggunakan aloksan monohidrat dapat menyebabkan keadaandiabetes pada tikus dalam awitan yang cepat dan stabil, yaitu 2-3 hari. Tikus-tikus Wistar dari setiap kelompok diinduksi menggunakan aloksan monohidrat $150 \mathrm{mg} / \mathrm{kgBB}$ dengan disuntik secara intraperitoneal ke dalam tikus. Berdasarkan analisis data, induksi dengan menggunakan aloksan monohidrat secara signifikan mampu meningkatkan kadar glukosa darah tikus pada seluruh kelompok denan rerata kenaikan $254,65 \mathrm{mg} / \mathrm{dL}$ dengan nilai $p<0,001$.

Bentonit merupakan sejenis mineral silika yang berasal dari abu vulkanik dan dapat ditemukan di wilayah Indonesia. ${ }^{13}$ Terdapat suatu lapisan unik yang terbentuk akibat ikatan kation-anion di dalam bentonit yang menyebabkan bentonit memiliki kemampuan menyerap dan emngembang yang sangat baik. Selain itu, permukaan luar bentonit disusun oleh muatan-muatan negatif yang akan menarik substrat bermuatan positif. Substratsubstrat tersebut akan diserap dan akan menempati lapisan unik di dalam bentonit

\section{KESIMPULAN}

Simpulan dari penelitian ini adalah bentonit terbukri dapat menurunkan kadar glukosa darah secara signifikan pada tikus terdapat perbedaan yang signifikan di antara kedua kelompok. Dari hasil tersebut disimpulkan bahwa rerata kadar glukosa setelah diberikan intervensi pada kelompok aquades adalah $291,2 \mathrm{mg} / \mathrm{dL}$, sedangkan kelompok bentonit 131,2mg/dL.

sehingga bentonit akan mengembang. ${ }^{14,15}$ Pada penelitian ini, bentonit di dalam usus menyerap glukosa dari dalam darah dan yang berada di dalam usus dan menyimpannya di dalam lapisan basal plate di dalam bentonit.

Penelitian mengenai daya serap bentonit di dalam usus makhluk hidup masih terbatas dan salah satinya adalah bentonit yang diberikan per orak terbukti mampu menurunkan kadar ureum dan kreatinin berlebih pada tikus yang diinduksi menjadi gagal ginjal akut. Menyerap ureum dan kreatinin yang berlebih yang berada di dalam darah dan mencegah absorpsi ureum dan kreatinin ke dalam aliran darah merupakan hasil dari mekanisme kerja bentonit. ${ }^{16}$ Selain itu, terdapat penelitian mengenai daya serap bentonit terhadap polisakarida, suatu polimer kompleks dari glukosa dengan menggunakan metode analisis kimia dan hasilnya menunjukkan bahwa bentonit mampu menyerap polisakarida tersebut. ${ }^{17}$

Keterbatasan penelitian ini adalah hanya menggunakan hewan coba tikus Wistar betina karena hewan betina lebih resisten terhadap diabetes sehingga belum dapat membuktikan adanya pengaruh dari jenis kelamin. Selain itu penelitian ini hanya dilakukan selama seminggu, sehingga belum diketahui efek jangka panjang dari bentonit.

Wistar yang sudah diinduksi aloksan monohidrat. 


\section{PENDANAAN}

Penelitian ini tidak didanai oleh sumber hibah manapun.

\section{KONFLIK KEPENTINGAN}

Tidak terdapat konflik kepentingan.

\section{DAFTAR PUSTAKA}

1. Powers AC. Diabetes melitus. Dalam: Longo D, Anthony F, editor. Harrison's principle of internal medicine. Edisi ke-18: McGraw-Hill; 2011.

2. Goldman I., Cecil RLF, Scafer AL. Type 2 diabetes mellitus. Dalam: Arend WP, Armitage JO, Clemmons DR, editor. Goldman's Cecil medicine. Edisi ke-24: Elsevier Health Sciences; 2011. Hlm. e237-1e-14.

3. Kumar V, Abbas AK, Fausto N, Aster $\mathrm{J}$, editor. Robbins and Cotran pathologic basis of disease. Edisi ke8: Elsevier Health Sciences; 2009.

4. Konsesus pengelolaan dan pencegahan diabetes melitus tipe 2 di Indonesia. Konferensi kerja perkumpulan endokrinologi Indonesia: Perkumpulan Endokrinologi Indonesia (PERKENI); 2011.

5. Waspadji. Buku ajar ilmu penyakit dalam. Edisi ke-3. Jakarta: Balai Penerbit FKUI; 1999.

6. Shaw J. Sicree R, Zimmet P. Global estimates of the prevalences of diabetes for 2010 and 2030. Diabetes Research and Clinical Practice. 2010; 87(1):4-14.

7. Sicree R., Shaw J, Zimmet P, Heart BIDI. The global burden: Diabetes and impaired glucose intolerance. IDF Diabetes Atlas; 2009:1-5.

8. Keputusan Menteri Kesehatan Republik Indonesia nomor 0584/Menkes/SK/VI/1995 tentang Sentra Pengembangan dan Penerapan Pengobatan Tradisional. 1995.

9. Undang-Undang no. 23 tahun 1992 tentang: Kesehatan. 1992.

10. Eaton JR. Healing clats of the world bentonite as used in pelotherapy, natural and alternative medicine. [diakses tanggal 13 Mei 2012].

Tersedia dari www.eytonsearth.org/introductionclays.php.

11. Eaton JR. Bentonite \& montmorillonite: Smectite clay minerals. [Diakses tanggal 13 Mei 2012]. Tersedia dari: www.eytonsearth.org/bentonitemontmorillonite.php.

12. Departemen Kesehatan Republik Indonesia. Pedoman pengujian dan pengembangan fitofarmaka: Penapisan farmakologi, pengujian fitokimia, dan pengujian klinik. Yayasan Pengembangan Obat Bahan Alam Phyto Medica. 1993;37:191.

13. Ampo. Tanah liat panggang khas Tuban. [Diakses tanggal 29 April 2012]. Tersedia dari: www.beriaunik.net/wisata/ampotanah-liat-panggang-khas-tuban.html.

14. Syuhada S, Wijaya R, Jayatin J, Rohman S. Modifikasi bentonit (clay) menjadi organoclay dengan penambahan surfaktan. Jurnal Nanosains \& Nanoteknologi. 2009;2(1):48-51.

15. Lubis G. Bentonit sebagai bahan baku industri di Sumatera Utara. Inovasi. 2008;5.

16. Cao Y, Long L, Ma Z, Tao X, Liu J, Zhou L. Effect of montmorillonite on diffusion or urea between blood and intestine and on absorption of intestine in rats. Zhong Yao Cai Journal of Chinese Medicine Materials. 2009; 32(2):249.

17. Parfitt, R. L., Greenland D.J. Adsorption of polysaccharides by montmorillonite. Soil Sci Soc Am J. 1970;34(6): 